\title{
The NMR View of Proteins
}

\author{
Authors: $\quad$ Kurt Wüthrich \\ Submitted: $\quad$ 20. December 2015 \\ Published: $\quad$ 20. December 2015 \\ Volume: 2 \\ Issue: 7 \\ Keywords: $\quad$ Nobel Prize in Chemistry, Protein Structures, Proteins in Body \\ Fluids, Structural Biology and Drug Development \\ DOl: $\quad$ 10.17160/josha.2.7.84
}

\section{JOSHA Jumualositumea Humanities and Arts}




\section{The NMR View of Proteins}

\section{Prof. Dr. Dr. h.c. mult. Kurt Wüthrich}

The Scripps Research Institute, La Jolla, CA, USA and ETH Zürich, Zürich, Switzerland

Correspondence: wuthrich@mol.biol.ethz.ch

Keywords: Nobel Prize in Chemistry, Protein Structures, Proteins in Body Fluids, Structural Biology and Drug Development

Kurt Wüthrich is the Cecil H. and Ida M. Green Professor of Structural Biology at The Scripps Research Institute, La Jolla, CA, USA, and Professor of Biophysics at the ETH Zürich, Zürich, Switzerland. He also directs research groups at the Universidad Federal do Rio de Janeiro in Brazil and at the iHuman Institute of ShanghaiTech University in China. His research interests are in molecular structural biology and structural genomics. His specialty is nuclear magnetic resonance (NMR) spectroscopy with biological macromolecules, where he contributed the NMR method of three-dimensional structure determination of proteins and nucleic acids in solution. The Wüthrich groups have determined a large number of macromolecular NMR structures, including the immunosuppression system cyclophilin A-cyclosporin A, the homeodomain-operator DNA transcriptional regulatory system, and prion proteins from humans, cattle and a variety of other species.

Kurt Wüthrich was born in Switzerland on October 4, 1938, is married to Marianne Briner, and has two children, Bernhard Andrew and Karin Lynn. He studied chemistry, physics and mathematics at the University of Bern from 1957-62. He then moved to the University of Basel, where he obtained the "Eidgenössisches Turn- und Sportlehrerdiplom" and a Ph.D. in inorganic chemistry (Prof. Silvio Fallab) in 1964. He was a postdoctoral fellow in Basel (Prof. S. Fallab) and at the University of California in Berkeley, CA, USA (Prof. R.E. Connick), and a Member of Technical Staff at Bell Telephone Laboratories in Murray Hill, NJ, USA (Biophysics Department, Dr. R.G. Shulman). In 1969 he joined the ETH Zürich (Privatdozent 1970, Assistant Professor 1972, Associate Professor 1976, Professor of Biophysics 1980, Chairman of the Department of Biology 1995-2000). Since 2001 he shares his time between the ETH Zürich and The Scripps Research Institute. Kurt Wüthrich's achievements have been recognized by the Prix Louis Jeantet de Médecine, the Kyoto Prize in Advanced Technology, the Nobel Prize in Chemistry, and by other awards and honorary degrees.

The Wüthrich group started work toward the NMR method for structure determination of biological macromolecules in solution in the 1970s with systematic studies on NOE (NOE: nuclear Overhauser effect) build-up and spin diffusion in proteins (1), the sequential assignment strategy for proteins (2) and, in joint projects with Richard R. Ernst, the development of two-dimensional NMR with biological macromolecules (3). A framework for 
NMR structure determination of proteins was formulated in 1982 (2). Among the threedimensional protein structures in solution solved by the Wüthrich laboratory, the bull seminal proteinase inhibitor (BUSI) was the first NMR structure of a globular protein (4). In the further development of the method, the structure determinations of metallothionein (5), the amylase inhibitor tendamistat (6), the Antennapedia homeodomain-BS2 operator complex (7), and the cyclosporin A-cyclophilin A complex (8) were of special interest. Prion proteins (PrP) have become a major research focus of the Wüthrich laboratory since 1994 (9-12).

Beyond three-dimensional structure determination, the Wüthrich team worked on additional methods developments. NMR was used to study biomacromolecular dynamics, solvation and function-related conformational equilibria (13-16). The introduction of transverse relaxationoptimized spectroscopy (TROSY) in 1997 (17) has made a wide spectrum of novel NMR experiments available for studies of larger biomacromolecular structures in solution. Applications in the Wüthrich laboratory include structure determinations of integral membrane proteins and studies of their solvation in water-soluble micelles (18), and characterization of the conformational states of individual macromolecular components in supramolecular structures with molecular weights up to $900 \mathrm{kDa}(19)$.

\section{References}

1. Gordon, S.L. and Wüthrich, K. (1978) J. Am. Chem. Soc. 100, 7094-7096. Transient proton-proton Overhauser effects in horse ferrocytochrome c.

2. Dubs, A., Wagner, G. and Wüthrich, K. (1979) Biochim. Biophys. Acta 577, 177-194. Individual assignments of amide proton resonances in the proton NMR spectrum of the basic pancreatic trypsin inhibitor; Wüthrich, K., Wider, G., Wagner, G. and Braun, W. (1982) J. Mol. Biol. 155, 311-319. Sequential resonance assignments as a basis for determination of spatial protein structures by high resolution proton nuclear magnetic resonance.

3. Anil-Kumar, Ernst, R.R. and Wüthrich, K. (1980) Biochem. Biophys. Res. Comm. 95, 1-6. A two-dimensional nuclear Overhauser enhancement (2D NOE) experiment for the elucidation of complete proton-proteon cross-relaxation networks in biological macromolecules; Wider, G., Macura, S., Anil Kumar, Ernst, R.R. and Wüthrich, K. (1984) J. Magn. Reson. 56, 207-234. Homonuclear two-dimensional ${ }^{1} \mathrm{H}$ NMR of proteins: experimental procedures.

4. Williamson, M.P., Havel, T.F. and Wüthrich, K. (1985) J. Mol. Biol. 182, 295-315. Solution conformation of proteinase inhibitor IIA from bull seminal plasma by ${ }^{1} \mathrm{H}$ nuclear magnetic resonance and distance geometry.

5. Schultze, P., Wörgötter, E., Braun, W., Wagner, G., Vašák, M., Kägi, J.H.R. and Wüthrich, K. (1988) J. Mol. Biol. 203, 251-268. Conformation of $\left[\mathrm{Cd}_{7}\right]$-metallothionein-2 from rat liver in aqueous solution determined by nuclear magnetic resonance spectroscopy.

6. Kline, A.D., Braun, W. and Wüthrich, K. (1988) J. Mol. Biol. 204, 675-724. Determination of the complete three-dimensional structure of the $\alpha$-amylase inhibitor Tendamistat in aqueous solution by nuclear magnetic resonance and distance geometry. 
7. Qian, Y.Q., Billeter, M., Otting, G., Müller, M., Gehring, W.J. and Wüthrich, K. (1989) Cell 59, 573-580. The structure of the Antennapedia homeodomain determined by NMR spectroscopy in solution: comparison with prokaryotic repressors; Otting, G., Qian, Y.Q., Billeter, M., Müller, M., Affolter, M., Gehring, W.J. and Wüthrich, K. (1990) EMBO J. 9, 3085-3092. Protein-DNA contacts in the structure of a homeodomain-DNA complex determined by nuclear magnetic resonance spectroscopy in solution.

8. Weber, C., Wider, G., von Freyberg, B., Traber, R., Braun, W., Widmer, H. and Wüthrich, K. (1991) Biochemistry 30, 6563-6574. The NMR structure of cyclosporin A bound to cyclophilin in aqueous solution; Kallen, J., Spitzfaden, C., Zurini, M.G.M., Wider, G., Widmer, H., Wüthrich, K. and Walkinshaw, M.D. (1991) Nature 353, 276-279. Structure of human cyclophilin and its binding site for cyclosporin A determined by X-ray crystallography and NMR spectroscopy.

9. Riek, R., Hornemann, S., Wider, G., Billeter, M., Glockshuber, R. and Wüthrich, K. (1996) Nature 382, 180-182. NMR structure of the mouse prion protein domain $\operatorname{PrP}(121-231)$.

10. Sigurdson, C.J., Nilsson, K.P., Hornemann, S., Heikenwalder, M., Manco, G., Schwarz, P., Ott, D., Rülicke, T., Liberski, P.P., Julius, C., Falsig, J., Stitz, L., Wüthrich, K. and Aguzzi, A. (2009) Proc. Natl. Acad. Sci. USA 106, 304-309. De novo generation of transmissible spongiform encephalopathy by mouse transgenesis.

11. Damberger, F.F., Christen, B., Pérez, D.R., Hornemann, S. and Wüthrich, K. (2011) Proc. Natl. Acad. Sci. USA 108, 17308-17313. Cellular prion protein conformation and function.

12. Christen, B., Damberger, F.F., Pérez, D.R., Hornemann, S. and Wüthrich, K. (2013) Proc. Natl. Acad. Sci. USA 110, 8549-8554. Structural plasticity of the cellular prion protein and implications in health and disease. The structure of the Antennapedia homeodomain determined by NMR spectroscopy in solution: comparison with prokaryotic repressors.

13. Wüthrich, K. and Wagner, G. (1975) FEBS Lett. 50, 265-268. NMR investigations of the dynamics of the aromatic amino acid residues in the basic pancreatic trypsin inhibitor.

14. Otting, G., Liepinsh, E. and Wüthrich, K. (1991) Science 254, 974-980. Protein hydration in aqueous solution.

15. Billeter, M., Güntert, P., Luginbühl, P. and Wüthrich, K. (1996) Cell 85, 1057-1065. Hydration and DNA recognition by homeodomains.

16. Liu, J.J., Horst, R., Katritch, V., Stevens, R.C. and Wüthrich, K. (2012) Science 335, 1106-1110. Biased signaling pathways in $\beta_{2}$-adrenergic receptor characterized by ${ }^{19} \mathrm{~F}$ NMR.

17. Pervushin, K., Riek, R., Wider, G. and Wüthrich, K. (1997) Proc. Natl. Acad. Sci. 94, 12366-12371. Attenuated $\mathrm{T}_{2}$ relaxation by mutual cancellation of dipole-dipole coupling and chemical shift anisotropy indicates an avenue to NMR structures of very large biological macromolecules in solution.

18. Fernández, C., Hilty, C., Wider, G. and Wüthrich, K. (2002) Proc. Natl. Acad. Sci. USA 99, 13533-13537. Lipid-protein interactions in DHPC micelles containing the integral membrane protein OmpX investigated by NMR spectroscopy.

19. Fiaux, J., Bertelsen, E., Horwich, A. and Wüthrich, K. (2002) Nature 418, 207-211. NMR analysis of a 900K GroEL-GroES complex. 